Southern Methodist University

SMU Scholar

Faculty Journal Articles and Book Chapters

Faculty Scholarship

2000

\title{
The Parade of Sovereignties: Establishing the Vocabulary of the New Russian Federalism
}

Jeffrey D. Kahn

Southern Methodist University, Dedman School of Law

Author ORCID Identifier:

(iD) https://orcid.org/0000-0002-8857-5647

\section{Recommended Citation}

Jeffrey Kahn, The Parade of Sovereignties: Establishing the Vocabulary of the New Russian Federalism, 16 Post-Soviet Affairs 58, 2000

This document is brought to you for free and open access by the Faculty Scholarship at SMU Scholar. It has been accepted for inclusion in Faculty Journal Articles and Book Chapters by an authorized administrator of SMU Scholar. For more information, please visit http://digitalrepository.smu.edu. 


\section{The Parade of Sovereignties: \\ Establishing the Vocabulary of the New Russian Federalism}

Jeff Kahn ${ }^{1}$

\begin{abstract}
On the basis of extensive on-site interviews and documentary sources, the author interprets the dynamics of the collapse of the Soviet Union by analyzing the cascade of sovereignty declarations issued by republics of the USSR as well as by autonomous republics and other subunits of the Russian republic, in 1990-1991. Interrelationships among the declarations, and other putative causes of their content and timing, are explored. A case study of Tatarstan is provided. The study also analyzes the impact of the process on subsequent Russian approaches to federalism.
\end{abstract}

$I^{\mathrm{n} a}$

a span of thirty-three months, forty-one former units of the Soviet Union declared themselves to be sovereign states, an average of one declaration every twenty-three days. This was the "Parade of Sovereignties," which reached a furious marching pace in the latter half of 1990 following the June declaration of the linchpin republic of the Soviet Union, the Russian Soviet Federated Socialist Republic. Only sixteen of these fortyone republics actually aspired to independence beyond sovereignty. Fifteen seceded without war and with relatively little bloodshed; the exception, Chechnya, can still hardly be considered either independent or sovereign over its affairs, at the cost of tens of thousands of lives. ${ }^{2}$

'The author received his D.Phil. in Politics from Oxford University (St. Antony's College) in July 1999. He is grateful to George Breslauer, Archie Brown, and Alfred Stepan for their helpful comments. Some of the themes of this article were originalty presented at a semina at the Centre for Russian and East European Studies, St. Antony's College, Trinity Term 1999 ${ }^{2}$ Estimates of the number of deaths in the first Chechen War (1994-1996) range from 20,000 by Anatol Lieven (1998, p. 108) to 80,000 by General Aleksandr Lebed' (Brown, 1999, p. 58) to 100,000 by Grigoriy Yavlinsky (1997, p. 4). Thus far, thousands have died in the second war, launched in fall 1999 .
Academic analysis of these Declarations of State Sovereignty has tended to downplay their significance. In the case of Union Republics, declarations of independence are considered to be of greater importance than earlier declarations of sovereignty, precursors to the real matter at hand. In the case of former Autonomous Soviet Socialist RepublicsASSRs, now primarily the twenty-one republics of the Russian Federation ${ }^{3}$ - the failure of these republics to follow the pattern of secession established by Union Republics is taken as evidence that the objectives set in these declarations were superficial at best, unachieved (and unachievable) at worst. However, the declarations issued by Supreme Soviets across the RSFSR were very different from the declarations launched by other Union Republics. These were, quite explicitly, declarations of sovereignty - not independence - and thus should be assessed in that considerably different light. They have had a deep and far-reaching effect on the conceptual and institutional development of the new Russian federalism and may be viewed as the precursors to the bilateral treaties that have created such an current asymmetry in Russian federal relationships, and which even threaten to supplant the federal Constitution in relative importance to republics (as the 1993 Constitution supplanted the 1992 Federation Treaty). This article examines the "Parade of Sovereignties" in detail before exploring how this remarkable period at the end of Soviet history has so shaped the start of Russia's beleaguered federal development.

\section{THE TIMING OF DECLARATIONS OF SOVEREIGNTY}

A declaration of sovereignty is an act of defiance. It is the public announcement by a subordinate government of the fact or intention that its relationship to the once-higher authority has been or is about to be deliberately and unilaterally changed. Such statements are rarely spontaneous; rather they are products of calculation by political actors driven by specific (if not always clearly articulated) political and personal goals. The political actors directly responsible for drafting the declarations analyzed here were affected by both local interests and external catalysts to action. In short, a broadly homogeneous group of political elites at the top of ASSR government and Party structures perceived a weakening in the hierarchical system that had previously enforced constraints and rewarded privileges for them. Simultaneously, these men were confronted with new constraints by increasingly mobilized electorates that were soon empowered to reward the most prized and central of privileges: elected office. For republican elites with a preference to retain their positions of power, the incentives to break with a weakening central authority grew.

${ }^{3}$ The RSFSR contained sixteen ASSRs; Georgia contained three (Abkhaziya, Azariya, and South Ossetiya), Azerbaijan one (Nakhichevan), and Uzbekistan one (Karakalpak). In the RSFSR, the autonomous oblasti of Adygeya, Gorno-Altay, Karachayevo-Cherkessiya, and Khakassiya successfully declared themselves to be republics, and the Chechen-Ingush republic split into two republics. Thus, the total number of republics in Russia today is twenty-one.
lontich 
Table 1. The Parade of Sovereignties

\begin{tabular}{|c|c|c|c|c|c|c|c|c|}
\hline$\frac{1988}{\text { Estonia Nov. } 16}$ & \multicolumn{2}{|c|}{1989} & \multicolumn{4}{|c|}{1990} & \multicolumn{2}{|c|}{1991} \\
\hline Estonia Nov. 16 & $\begin{array}{l}\text { Lithuania } \\
\text { Latvia } \\
\text { Azerbaijan } \\
\text { Georgia } \\
\text { Belarus }\end{array}$ & $\begin{array}{l}\text { May } 18 \\
\text { July } 29 \\
\text { Sept. } 23 \\
\text { Oct. } 12 \\
\text { Dec. } 7\end{array}$ & $\begin{array}{l}\text { RSFSR } \\
\text { Uzbekistan } \\
\text { Moldova } \\
\text { Ukraine } \\
\text { N. Ossetiya } \\
\text { Kareliya } \\
\text { Khakassiya } \\
\text { Turkmenistan } \\
\text { Arnenia } \\
\text { Abkhaziya } \\
\text { Tadzhikistan } \\
\text { Komi } \\
\text { Tatarstan } \\
\\
\text { Udmurtiya } \\
\text { S. Ossetiya } \\
\text { Yakutiya } \\
\text { Chukotka }\end{array}$ & $\begin{array}{l}\text { June } 12 \\
\text { June } 20 \\
\text { June } 23 \\
\text { July } 16 \\
\text { July } 20 \\
\text { Aug. } 9 \\
\text { Aug. } 15 \\
\text { Aug. } 22 \\
\text { Aug. } 23 \\
\text { Aug. } 25 \\
\text { Aug. } 25 \\
\text { Aug. } 29 \\
\text { Aug. } 30 \\
\text { Sept. } 20 \\
\text { Sept. } 20 \\
\text { Sept. } 27 \\
\text { Sept. } 29\end{array}$ & $\begin{array}{l}\text { Buryatiya } \\
\text { Koryak } \\
\text { Komi-Pernyak } \\
\text { Bashkortostan } \\
\text { Kalmykiya } \\
\text { Yamal-Nenets } \\
\text { Marii El } \\
\text { Chuvashiya } \\
\text { Gorno-Altay } \\
\text { Kazakhstan } \\
\text { Kirghizstan } \\
\text { Tuva } \\
\text { Karachay- } \\
\text { Cherkessiya } \\
\text { Checheno- } \\
\text { Ingushetiya } \\
\text { Mordova }\end{array}$ & $\begin{array}{l}\text { Oct. } 8 \\
\text { Oct. } 9 \\
\text { Oct. } 11 \\
\text { Oct. } 11 \\
\text { Oct. } 18 \\
\text { Oct. } 18 \\
\text { Oct. } 22 \\
\text { Oct. } 24 \\
\text { Oct. } 25 \\
\text { Oct. } 26 \\
\text { Oct. } 28 \\
\text { Nov. } 1 \\
\text { Nov. } 17 \\
\text { Nov. } 27 \\
\text { Dec. } 8\end{array}$ & $\begin{array}{l}\text { Kabardino- } \\
\text { Balkariya } \\
\text { Dagestan } \\
\text { Adygeya }\end{array}$ & $\begin{array}{l}\text { Jan } 31 \\
\text { May } 15 \\
\text { July } 2\end{array}$ \\
\hline
\end{tabular}

The timing and speed of these declarations, however, suggests that still another factor was involved. Why should republican elites choose to "make the break" with such an untested approach as a declaration of sovereignty? Who would dare to be first? In part, the answers are suggested by the very metaphors used to describe the phenomenon: parade, cascade, deluge, chain reaction, etc. By their natures conservative creatures, ASSR nomenklatura elites needed evidence that their preferences for more autonomy were actually attainable. Boris Yel'tsin's real and rhetorical maneuvers and the example he provided in control of the RSFSR Congress of People's Deputies demonstrated what was feasible and provided the necessary catalyst. Republican elites, a few explainable time lags notwithstanding, quickly chose to follow that lead. A cascade effect clearly manifested itself: the "Parade of Sovereignties."

The RSFSR was the seventh of the fifteen union republics (SSRs) to declare sovereignty. Not a single autonomous republic (ASSR) within Russia utilized the same strategy until the First Russian Congress blazed

\footnotetext{
4"Cascade effects" in the late Soviet period were not limited to the Parade of Sovereignties. Indeed, some scholars, most notably Steven Solnick, have employed neoinstitutional approaches to organizational hierarchy and principal-agent relations to show how a "chain reaction of defiance or defection" can lead in certain circumstances to total system collapse; see Solnick (1998, P. 8 and passim.).
}

the trail..$^{5}$ In the next six months, fourteen of the then sixteen ASSRs situated within Russia would follow suit.

As Table 1 suggests, the Parade of Sovereignties was marched to the beat of several different drummers. Union republics with past histories of independence led well ahead of their counterparts lodged within Russia. Pockets of regional influence seem to exist: Yakutiya and Chukotka, Marii $\mathrm{EI}$ and Chuvashiya. No less significant, sovereign declarations are clustered in small periods of days rather than more evenly distributed. Such clusters suggest that republics were not only aware of other declarations, but encouraged by them.

This was a confusing time for the ruling elite, who paid close attention to the declarations occurring around them. ${ }^{6}$ In Marii El, the process of sovereignization "in the beginning was met suspiciously by the partysoviet leadership, the corps of deputies. But then the party-economic activists, meeting under the screen of the Supreme Soviet of the republic, comprehended what sort of benefits this might promise in opposition to democratic re-organization begun by the new Russian leadership" (Chervonnaya and Guboglo, 1996, p. 51). Unsure what to do, many habitually looked to Russia; one of the principal drafters of Bashkortostan's declaration recalled: "It was not clear if Russia left the Union what would be the fate of the ASSRs - if Russia declared independence, then what to do?" (Samigullin, 1997). In the absence of clear signals, most Supreme Soviets initially chose the safety of a wait-and-see approach as declarations in the union republics began in November 1988. A strong influence was the First Russian Congress, where delegations of regional elites actively participated in debates over the RSFSR Declaration. Subject to contentious debate was Article 9, which "confirmed the need to broaden substantially" the rights of sub-units of the Federation. This was an obvious invitation for republics to assert their own autonomy. These debates will be discussed in greater detail below.

Regional elections provided another direct incentive to republican elites to sponsor their own sovereignty campaigns. Elections rang the death knell to the days of unchallenged democratic centralism as regional politicians became aware that soon they might be more accountable to their local constituents than to their bosses in Moscow.

${ }^{5}$ Union republics were much better placed institutionally to declare sovereignty and, ultimately, independence: because they were nominally incorporated into the USSR by treaty, a mately, independence: because they were nominally incorporated into the USSR by treaty, a
claim to equal status with the RSFSR was more easily justified and defended. Autonomous republics were established ex nihilo by unilateral administrative decisions. Directives of the RSFSR had supremacy over the limited autonomy of ASSRs.

${ }^{6}$ E.g., this exclamation from Boris Pavlov: "Comrades! Several days ago the Buriat Republic became sovereign. In the Declaration is written that it remains a component of Russia and the USSR. The announcer of the Central television, who saw this broadcast, especially emphasized this" (Stenograficheskiy otchot Verkhounogo Soveta Baslikirskoy SSR, 1991, p. 158). 
Table 2. Electoral Effect on Declarations ${ }^{\mathrm{a}}$

\begin{tabular}{|c|c|c|c|c|}
\hline Republic & $\begin{array}{l}\text { Chairman of } \\
\text { Supreme Soviet }\end{array}$ & $\begin{array}{l}\text { Date } \\
\text { elected }\end{array}$ & $\begin{array}{l}\text { Date of } \\
\text { declaration }\end{array}$ & $\begin{array}{l}\text { Time } \\
\text { elapsed }\end{array}$ \\
\hline North Ossetiya & Akhsarbek Galazov ${ }^{b}$ & March 1990 & July 20, 1990 & 5 months \\
\hline Kareliya & Viktor Stepanov & April 1990 & August 9, 1990 & 5 months \\
\hline Khakassiya & Valeriy Shtygashev*c & Spring 1990 & August 15, 1990 & 5 months \\
\hline Komi & Yury Spirodonov & April 1990 & August 29, 1990 & 5 months \\
\hline Tatarstan & Mintimer Shaymiyev & April 1990 & August 30,1990 & 5 months \\
\hline Udmurtiya & Valentin Tubylov & April 1990 & Sept. 20,1990 & 6 months \\
\hline Sakha & Mikhail Nikolayev & March 1990 & Sept. 27,1990 & 7 months \\
\hline Buryatiya & Sergey Buldayev & March 1990 & October 8,1990 & 7 months \\
\hline Bashkortostan & Murtaza Rakhimov & April 1990 & October 11, 1990 & 7 months \\
\hline Kalmykiya & Vladmir Basanov & March 30, 1990 & October 18,1990 & 7 months \\
\hline Marii El & Valeriy Zotin & August 1990 & October 22,1990 & 2 months \\
\hline Chuvashiya & Anatoliy Leont'yev & April 1990 & October 24,1990 & 7 months \\
\hline Gorno-Altay & V.I. Chaptynov* & March 1990 & October 25,1990 & 7 months \\
\hline Tuva & Chimit-Dorzhu Ondar & April 1990 & November 1, 1990 & 7 months \\
\hline $\begin{array}{l}\text { Karachay- } \\
\text { Cherkessiya }\end{array}$ & Valentin Lesnicherko & March 1990 & November 17,1990 & 9 months \\
\hline $\begin{array}{l}\text { Checheno- } \\
\text { Ingushetiya }\end{array}$ & Doku Zavgayev & March 1990 & November 27,1990 & 9 months \\
\hline Mordova & Anatoly Berezin & April 1990 & December 8, 1990 & 9 months \\
\hline $\begin{array}{l}\text { Kabardino- } \\
\text { Balkariya }\end{array}$ & Valeriy Kokov & April 1990 & January 31, 1991 & 10 months \\
\hline Dagestan & $\begin{array}{l}\text { Magomedali } \\
\text { Magomedov }\end{array}$ & April 1990 & May 15, 1991 & 13 months \\
\hline Adygeya & Aslan Dzharimov & March 1990 & July 2, 1991 & 17 months \\
\hline
\end{tabular}

an the case of the four autonomous oblasti that later changed status to republics (Altay, Adygeya, Karachayevo-Cherkessiya, and Khakassiya), the date of election to the oblast soviet is shown; Mann (1990); McFaul and Petrov (1997).

'Boldface indicates that remained presidents of republics through 1998.

'Asterisks indicate remained chairmen of new republican legislatures.

Keeping in mind that work often began on a draft declaration several months before it was officially ratified, the high place such documents had on the political agenda of newly elected republican elites becomes clear. A majority of these men (in boldface) remained presidents of their republics through 1998; those with asterisks are chairmen of the new republican legislatures. " Designing the "rules of the game" paid significant political dividends, as the next section examines in further detail.

\footnotetext{
${ }^{7}$ Chaptynov died in office in August 1997
}

Table 3. Ethnic Composition ${ }^{a}$

\begin{tabular}{|c|c|c|c|c|}
\hline $\begin{array}{l}\text { Eventual republics in } \\
\text { declaration sequence }\end{array}$ & $\begin{array}{l}\text { Percent } \\
\text { Russian }\end{array}$ & Rank & $\begin{array}{l}\text { Percent titular } \\
\text { nationality }\end{array}$ & Rank \\
\hline 1. North Ossetiya & 29.9 & 17 & 53 & 5 \\
\hline 2. Kareliya & 73.6 & 2 & 10 & 20 \\
\hline 3. Khakassiya & 79.5 & 1 & 11.1 & 19 \\
\hline 4. Komi & 57.7 & 8 & 23.3 & .16 \\
\hline 5. Tatarstan & 43.3 & 11 & 48.5 & 6 \\
\hline 6. Udmurtiya & 58.9 & 7 & 30.9 & 13 \\
\hline 7. Sakha & 50.3 & 9 & 33.4 & 10 \\
\hline 8. Buryatiya & 70 & 3 & 24 & 15 \\
\hline 9. Bashkortostan & 39.3 & 13 & 21.9 & 18 \\
\hline 10. Kalmykiya & 37.7 & 14 & 45.4 & 7 \\
\hline 11. Marii El & 47.5 & 10 & 43.3 & 8 \\
\hline 12. Chuvashiya & 26.7 & 18 & 67.8 & 2 \\
\hline 13. Gorno-Altay & 60.4 & 6 & 31 & 12 \\
\hline 14. Tuva & 32 & 15 & 64.3 & 3 \\
\hline 15. Karachay-Cherkessiya & 42.4 & 12 & 40.9 & 9 \\
\hline 16. Checheno-Ingushetiya & 23.1 & 19 & 70.7 & 1 \\
\hline 17. Mordova & 60.8 & 5 & 32.5 & 11 \\
\hline 18. Kabardino-Balkariya & 31.9 & 16 & 57.6 & 4 \\
\hline 19. Dagestan & 9.2 & 20 & 27.5 (Avars) & 14 \\
\hline 20. Adygeya & 68 & 4 & 22.1 & 17 \\
\hline
\end{tabular}

'Based on 1989 Census, as reprinted in Argumenty i fakty (March 1991).

Ethnic composition as a possible factor in the speed with which republics declared sovereignty is not a very strong explanatory variable. Autonomous republics (though not the ethnic groups for which they are named) are for the most part artificial artifacts of Bolshevik administrative planners. In twelve of the then twenty ASSRs, Russians outnumbered the titular nationality. As Table 3 shows, no discernible pattern can be detected that relates ethnic composition to a timetable of declarations. Republics with predominantly Russian populations appear at the beginning (Kareliya -73.6 percent Russian; Khakassiya -79.5 percent Russian) and the end (Adygeya -68.0 percent Russian; Mordova -60.8 percent Russian) of the Parade of Sovereignties. Likewise, republics with predominantly titular ethric populations are just as randomly distributed: neighboring North Ossetiya and Kabardino-Balkariya both rank in the top five republics in terms of ethnic homogeneity, while North Ossetiya was the first to declare sovereignty and Kabardino-Balkariya among the last. 
Time lags are further explained by particular events that explicitly encouraged autonomous republics to follow the path of union republics. Two obvious events are the RSFSR declaration of sovereignty and Boris Yel'tsin's 22-day tour of the Russian regions later that summer. As mentioned above, ASSRs sent delegations to the First Congress, which drafted Russia's declaration, where they paid close attention to the arguments and actions of union republics. Yel'tsin's whirlwind speaking tour, which took him from Primorskiy Kray to the heart of European Russia, was Yel'tsin's first junket following his election as Chairman of the RSFSR Supreme Soviet. While in Kazan', Yel'tsin made one of the most quoted and inflammatory statements of his career: "Take as much independence as you can hold on to." ${ }^{8}$ Between Russia's declaration and Yel'tsin's summer 1990 campaign designed to encourage regional activism, only one autonomous republic declared sovereignty-North Ossetiya in late July. Following Yel'tsin's tour, however, the deluge broke.

As Table 4 indicates, neither the declarations made by the union republics nor the declaration made by the RSFSR was sufficient to provoke similar activity in the autonomous republics. But given such unequivocal support by Yel'tsin, first several of the economically stronger regions and then the rest quickly followed with declarations of their own. With less to offer and more to lose than their union republic colleagues, leaders in autonomous republics needed more encouragement. Stirred by the declarations being made all around them, then prodded by internal elections, regional elites increasingly talked about the need for more autonomy. The catalyst for these declarations came from above and beyond the autonomous republics.

\section{MAKING THE "RULES OF THE GAME"}

Who led the drive to declare sovereignty in the autonomous republics? The nomenklatura, emerging national movements, spontaneous grassroots activists or some combination of them all might be considered. However, the evidence that emerges from stenographic records of republican legislatures, reports from official commissions, and nationalist and official state newspapers provides strong support for the argument that this was an extremely elite-dominated process. Social forces such as environmentalist or nationalist movements, while often in support of republican sovereignty, were rarely given opportunities for meaningful involvement in crafting the final product. Although "draft" declarations were frequently published in official newspapers alongside requests for public comment rarely can evidence be found to suggest that public participation played a substantial role in the drafting process other than to give the appearance

\footnotetext{
${ }^{8}$ As reported by Yelena Chernobrovkina, now politics editor for the newspaper, Yel'tsin said: "Berite stol'ko samostoyatel'nosti, skol 'ko smozhete uderzhat'..." (Vechernyaya kazan', August 10 1990 , p. 1). Four days later, speaking in Ufa, Bashkortostan, he declared: "Take that part of power that you will be able to swallow" (Guboglo and Arinin, 1997, pp. 31, 103).
}

Table 4. Event Effects on Declarations ${ }^{\mathrm{a}}$

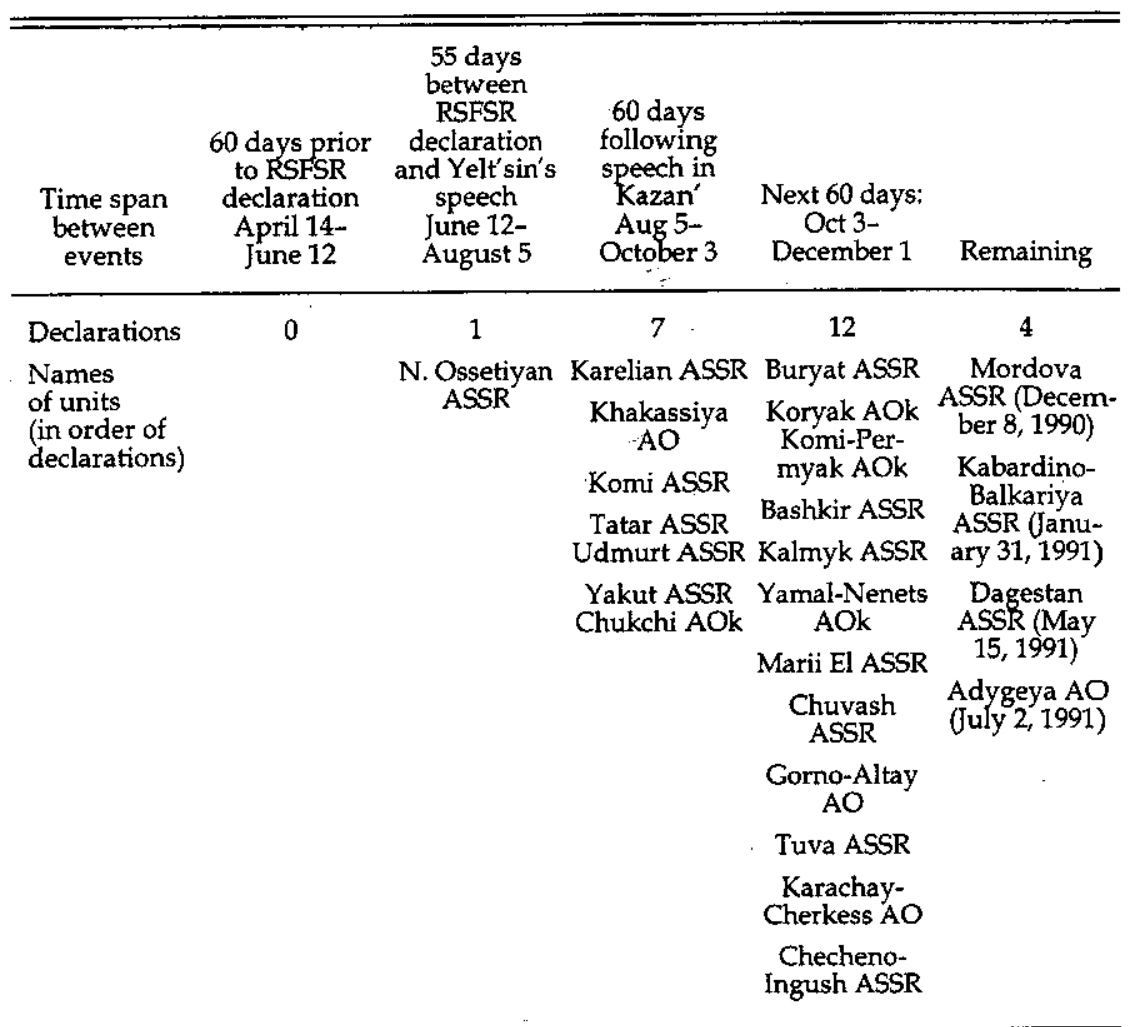

aASR $=$ Autonomous Republic; $\mathrm{AO}=$ Autonomous Oblast'; $\mathrm{AOk}=$ Autonomous $O$ krug

of widespread public support. Thus it should not be surprising that referendums played no part in the vast majority of sovereignty drives. Analyzing the "rules of the game" used in formulating declarations reveals as much about who made the rules as what they hoped to achieve in making them.

The ruling elite had very strong motives to take a leading role in declaring sovereignty. Democratic legitimacy was suddenly conferred on officials who had done little in their careers to earn it; those who decided to remain in government had every motivation to protect their positions in an increasingly uncertain environment. ${ }^{9}$ The case in Marii El applies in

${ }^{9}$ The clientalist-patron system entrenched in the regions was still a formidable obstacle, difficult for the still emerging and mostly Leningrad-and Moscow-based democratic opposition movements to penetrate successfully (Hanson, 1994, p. 15; McAuley, 1996, p. 40). 
many other republics: "Pseudo-sovereignty was found to be advantageous first and foremost for the party-nomenklatura at the top (who in the new conditions had been transferred to soviet and economic structures), for those who were commanding the enterprises and union ministries in the economy of the republic, the military-industrial complex, to which belonged more than 80 percent of gross production" (Chervonnaya and Guboglo, 1996, p. 52). The spring 1990 elections had overwhelmingly returned rank and file nomenklatury to republican and local soviets (Mann, 1990, pp. 17-20). In Tatarstan, one analysis indicates, 92 percent of the "new" ruling elite were former nomenklatura: "If in Moscow the second and third echelons of the nomenklatura came to power, then in Tatarstan it is wholly predominated by the first echelon" (Farukshin, 1994, p. 70). ${ }^{10}$ The same could be said of Siberian leaders, where a "phoenix-like regeneration of the nomenklatura" filled what had once been considered the second-rate posts of representative institutions (Hughes, 1994, p. 1136). Elections had empowered a constituency below the republican apparat at the same time that perestroyka had begun to weaken links "from above."

Republican elites did not leave the composition of drafting committees, and therefore the advancement of their own self-protective interests, to chance. The typical approach was for the Chairman or Presidium of the Supreme Soviet to appoint a special committee to compose a draft declaration. In Bashkortostan, for example, a core group of three wrote the first draft: Venir Samigullin, Ludmila Dol'nikova, and Vladimir Podelyanin. All three had legal backgrounds (Samigullin being a dotsent in law; the other two were candidates in law); in addition, Podelyanin was chairman of the Bashkir KGB (Sovetskaya Bashkiriya, October 18, 1990, p. 2; Samigullin, 1997). Their draft was then shown to a larger commission of approximately fourteen people before being published as one of three official drafts on August 10, 1990 in the official newspaper, Sovetskaya Bashkiriya (p. 2). ${ }^{11}$ In comparison with the final version, the drafts were twice as long (twenty or more articles as compared to ten) and more detailed on the interrelationship of Bashkir and Union structures (e.g., two of the three cite the Union law on the delimitation of powers and one notes that sovereignty actually "follows from the status of the republic as a subject of the USSR and Russian Federation"), but generally with few substantive differences either between drafts or with the final version. ${ }^{12}$

Other republics also published official drafts preceding the final announcement of sovereignty by (invariably) an overwhelming majority

${ }^{10}$ The author included 96 people as "ruling elite": president, vice-president, and leader of the presidential apparatus; from the Supreme Soviet: speaker, deputy speakers, and leaders of the secretariat; from the Cabinet: prime minister, deputy prime ministers, chairs of state committees, and head of the secretariat; and, finally, heads of city and raion administrations. ${ }^{11}$ The official drafts included one by the Soviet of Ministers and one by the Presidium of the Supreme Soviet. ${ }^{12}$ See, for example, Article 1 of the Council of Ministers draft (Sovetskaya Bashkiriya, August
10,1990, p. 2). of the Supreme Soviet. ${ }^{13}$ The draft published by the Kalmyk Supreme Soviet in early September (after its discussion in mid-August) was essentially the same as the final version passed in late October (Sovetskaya Kalmykiya, September 7,1990). A concise five-articled "alternative variant" offered by one Kalmykian People's Deputy in early October appeared to be more a public relations exercise than a genuine alternative in the official state newspaper (Sovetskaya Kalmykiya, October 6, 1990, p. 2). In Komi, the Party newspaper solicited the opinions of citizens about its published draft. However, the final version approved three weeks later manifested nothing but superficial changes (Krasnoye znamya, August 2, 1990, p. 1). Nongovernment drafts seem to have had little influence, despite calls for public participation. ${ }^{14}$ The declaration accepted by the Yakut-Sakha Republic three weeks following the publication of an official draft differed by only one article and one clause; both documents were otherwise virtually identical (Sotsialisticheskaya Yakutiya, September 2, 1990, p. 2). An "alternative draft" published in the interim seems to have had no impact whatsoever (Yegorov, in Sotsialisticheskaya Yakutiya, September 15, 1990, p. 2). ${ }^{15}$ In Buryatiya, the openness of the process and independence of different groups working on drafts is also called into question by the close similarity between drafts. ${ }^{16}$

Republican elites exercised tight control over the composition of drafting committees and the content of their working drafts. It should not be surprising, therefore, that ratification of these documents was also carefully circumscribed. Referendums played almost no role in the twin processes of ratification and legitimization of declarations of sovereignty. Although the First Russian Congress, with close to a thousand deputies, could in some sense pose as a special assembly convened for extraordinary

${ }^{13}$ The vote at the 3 rd Session of the Bashkir Supreme Soviet was 245 in favor, 1 against, 4 abstentions, 6 not voting, and 19 absent (see Sovetskaya Bashkiriya, October 16, 1990, p. 2). In Kalmykiya the vote on October 18 at an extraordinary session of the Supreme Soviet was unarimous (see Ilyumzhinov and Maksimov, 1997, p. 155).

${ }^{14}$ Two drafts appeared on July 13, 1990. One, by Gennadiy Yushkov, a writer and principal ${ }^{14}$ Two drafts appeared on July 13, 1990. One, by Gennadiy Yushkov, a writer and principal
founder of the national movment "Komi Kotyr," proposed legislative and executive institutions and unification with the Komi-Permyak Autonomous Okrug, none of which appear in the government's final version. Another, by a republican people's deputy and then-cochairman of Komi Kotyr, Vitaliy Osipov, was more comparable to that of Yushkov than to any other. His version of a bicameral legislature foresaw one house for Komi (possessing a veto on disputed questions) and one house for all other nationalities in the republic (Krasnoye znamya, July 13, 1990)

${ }^{15}$ Dmitriy Mironov, in his comprehensive account of the state-building process in Sakha, reports that in addition to the official draft, a group of republican people's deputies and members of the National Front and the national movements "Sakha keskile" and "Sakha omuk" also presented drafts, though what impact these had on the official version is not discussed (Mironov, 1996, pp. 54-55, 58).

${ }^{16}$ For a rough draft by the procuracy, see Pravda Buryatii (September 9, 1990, p. 4). For one by the Council of Ministers, see Pravda Buryatii (October 3, 1990, p. 3). The composite rough draft the Council of Ministers, see Pravda Buryatil (October 3, Presidium of the Supreme Soviet is published in Pravda Buryatii (October 6,1990, p. 1) 
purposes like declaring sovereignty, the supreme soviets of the autonomous republics had been elected with no such special mandate. From 1987 to 1993, thirty-three referendums were held in Eastern Europe and the former Soviet Union; 12 of these sought popular approval for sovereignty or independence (Brady and Kaplan, 1994, pp. 179-180) ${ }^{17}$ Of the fifteen union republics that ultimately became independent states, eight held referendums on the question of independence and two held referendums on state sovereignty, with high percentages for voter turnout and approval of the referendum question (Brady and Kaplan, 1994, pp. 193-194). In the autonomous republics, not a single referendum was held on questions of either sovereignty or independence until December 1991. These few, late referendums, when they did occur, only occurred as part of the tactics of secession (Ingushetiya from Chechnya) and in the early phases of negotiating bilateral treaties (Tatarstan and Bashkortostan). ${ }^{18}$ In any event, these referendums were focused neither on independence from the Russian Federation (in the sense of referendum questions in union republics regarding the Soviet Union) nor on increasing the legitimacy of existing declarations through a popular vote.

Though every declaration was made "in the name of the people," the role actually played by the electorate was a very passive one. Drafting committees were composed of high-level government elites appointed by the Chairman of the Supreme Soviet. Contrary to the old Soyiet tradition of proletarian representatives on everything from People's Courts to Supreme Soviet Presidiums, the common citizen was not invited to sit with selected experts on drafting commissions. Rough drafts in newspapers were usually published with insufficient time for reaction before final votes were taken in republican parliaments. No autonomous republics turned to referendums to convey an extra measure of popular legitimacy on the final document. In many ways, these drafting processes were the antithesis of the grassroots national movements which preceded them.

\section{THE CASE OF TATARSTAN}

The Republic of Tatarstan, the acknowledged leader of the republican movement, provides an example of just how elite-dominated the declaration process could be. Despite the existence of comparatively stronger and more mobilized political forces in Tatarstan than elsewhere pushing for their own versions of declarations of sovereignty, the president of the

\footnotetext{
${ }^{17} \mathrm{Of}$ the remaining twenty-one referendums, nine ratified constitutions or new forms of government and twelve dealt with specific policy issues.

${ }^{18}$ On December 1, 1991, the People's Council of Ingushetiya held a referendum on the sovereignty of Ingushetiya within the RSFSR and on the return of territory lost during Stalinist purges in 1944 . Voter participation amounting to 73.7 percent and a 92.5 percent approval vote were claimed. Tatarstan and Bashkortostan held referendums on March 21, 1992 and April 25, 1993, respectively. In Tatarstan, 82 percent of the electorate participated, 61.4 percent approving of Tatarstan's sovereign status.
}

republic, Mintimer Shaymiyev, ably manipulated political structures to dominate the process. Even in a republic in which grassroots movements were eager and able to construct their own drafts, the political elite still insisted on an exclusive role. Numerous drafts were published in official papers during August 1990. Alone on one side of the spectrum was the draft of Alexander Shtanin, a coordinator for the opposition group "People's Power" (Narodnaya vlast'). This draft is remarkable for its repeated description of republican sovereignty within the framework of the RSFSR and the Union, its explicitly multinational references to the rights inherent in new Tatarstan citizenship, and the absence of declamatory clauses commandeering property and resources. ${ }^{19}$ On the other extreme was the draft prepared by the Tatar Public Center, a nationalist organization, whose preamble reference to the glories of Tatar independence from the eleventh to the sixteenth centuries hinted at the extreme nationalist stance expounded in a rambling 36-article declaration. Only the Tatar language was listed for protection (Art. 3), and "violent acts against the national statehood of Tatariya," by virtually any group or person were subject to prosecution according to the law. Another draft, by the "Citizens Committee of Tatariya" also mentioned medieval glories, but limited itself to a terse three-article exposition of state sovereignty as a subject of international law, leaving the rest to later legislation. ${ }^{20}$

This juxtaposition of such different views of sovereignty might suggest that a genuine public debate on the question had occurred. This was true only to a very limited extent. Certainly Shtanin's draft was independently created. But its opposite, the Tatar Public Center (or TOTs, its Russian acronym), was not. While nationalist sentiment had always existed in Tatarstan, the chairman of the Supreme Soviet and future president, Mintimer Shaymiyev, harnessed this force for his own interests. TOTs was not a spontaneous creation spawned by nationalist sentiment, but an organization engineered from the top echelons of the Tatar elite. A key founder and the lead ideologist for the Tatar Public Center was Raphael Khakimov, still one of Shaymiyev's closest political advisors (Toropov, 1992, pp. 6, 14; Sultanov, 1997; Belyayev, 1997). ${ }^{21}$ As Vladimir Belyayev, a political scientist and member of the democratic opposition recalls:

I do not think Shaymiyev created an ethno-territorial movement. He just played it up. In his time, he was helping the Tatar national movement, making it easier for them to register, finding places for them to meet, finance, etc. He let, or even ordered, directors of enterprises to bring crowds to the "Square of Liberty," the central

${ }^{19}$ For example, article five reads: "The TASSR is united with other republics in a federation and a union on the basis of treaties and respects the sovereign rights of republics, the federation, and unions."

${ }^{20}$ For both drafts, see Sovetskaya Tatariya, August 8, 1990, p. 2.

${ }^{21}$ Belyayev notes that Shaymiyev's administration is "constantly changing" with members of Tatar national movements. 
square of Kazan'. Then he could literally refer to the "will of the people." (Belyayev, 1997; see also Toropov, 1992, p. 6).

As Belyayev put it, Shaymiyev "understood when it was time to sit on the Tatar nationalist horse" (Hoffman, Washington Post, June 16, 1997, p. A1). An editor from Vechernyaya Kazan', one of the few relatively independent newspapers in the republic, recalls how Shaymiyev "manipulated the nationalists in a very clever way," orchestrating large crowds to demonstrate in Lenin Square. "It was a controlled movement," she recalls, "and they obediently retreated" when their presence was no longer politically expedient (Chernobrovkina, 1997). ${ }^{22}$

Just as Shaymiyev controlled the nationalist movement, he carefully orchestrated the proceedings of the Supreme Soviet, which he chaired. Examination of the stenographic records of sessions when the declaration was on the agenda reveals how Shaymiyev rigidly directed the course of debates. Ivan Grachev, chairman of the group "Equality and Law," was one of the only outspoken opponents. In 1990, Grachev led the opposition against Shaymiyev as a deputy to the republic's Supreme Soviet. During one of the final sessions before accepting the declaration, he interrupted the debate in order to question the competencies and composition of commissions reviewing questions of sovereignty. He insisted that changes first needed to be made to the republic's constitution and guarantees to "be sure that power in the republic is transmitted to the people" (Stenograficheskiy otchot Verkhounogo Soveta TASSR, 1990, p. 13). Shaymiyev ignored the comments, but after several minutes Grachev rose again to complain that deputies were being deceived by promises that structural reforms to government would commence after the declaration was accepted. Shaymiyev announced from the chair that he was switching off Grachev's microphone (Stenograficheskiy otchot Verkhovnogo Soveta TASSR, 1990, p. 24). Shaymiyev was adept at silencing opposition in the Supreme Soviet and directing floor votes with unsubtle hints as to their proper outcome. At one point, in true Soviet style, the arrival of hundreds of admiring telegrams was announced to the convened deputies. ${ }^{23}$

On August 31, the day after the vote declaring sovereignty, excerpts from the debate in the Supreme Soviet on August 29 were published under the heading "The Main Question on the Agenda." Ostensibly this was for the benefit of citizens; however, given the tenor of the times and the choice of excerpts published, a more politicized objective seems likely. Having drafted the most sharply worded declaration to date, Shaymiyev's team

${ }^{22}$ In fact, at least some members of TOTs are extremely resentful, though relatively powerless at the moment: "Shaymiyev does not fear the nationalist movement because we are weak today. Shaymiyev, the KGB and the Russian security forces fragment because we are weak to unite" (Zaymullin, 1997). Another member was forces fragmented us, but we are trying There are hundreds of thousands like me. Assimilation of Tatar expressive: "I am not calm. want our language and culture back, and the only way to guarantee that is through Tatar
statehood" (Urazayev, 1997). worked now to demonstrate that the alternatives could have been still worse as far as Moscow should be concerned. Their message to the center: accept Shaymiyev's approach as the most moderate path available. The chairman of the Supreme Soviet commission on nationalities questions, R.A. Yusupov, gave a thinly veiled warning that anything less than full sovereignty and equality for Tatarstan would lead to serious weakening of the friendship between peoples, a prospect the center dreaded (Sovetskaya Tatariya, August 31,1990, p.1). Particularly odd was the introduction of an alternative draft declaration proposed by R.R. Sirazeyev. This draft was far more strident than the official draft scheduled for a vote: utterly rejecting the USSR's legal authority and establishing dual citizenship (including separate passports and migration policy). In harsh language, the document noted that the sovereign republic "will not answer for the debts of the Union," meanwhile expropriating all Soviet property and resources located in Tatarstan (Sovetskaya Tatariya, August 31, 1990, p. 1). There seemed little point in proposing such a strongly worded new draft so late in the day, let alone publishing excerpts for public consumption, except to produce a special spectacle for Moscow. The irony was probably lost at the time that Sirazeyev was the chief director of the Tatar state theatre.

\section{CARVING AUTONOMY OUT OF SOVEREIGNTY}

In terms of the eventual formation of the Russian Federation, the RSFSR Declaration of State Sovereignty, accepted on June 12, 1990 by a large majority (907-13, with nine abstentions) at the First Russian Congress of People's Deputies, was the most important declaration of the Parade of Sovereignties. This was true for several reasons. First, to a far greater degree than preceding declarations by other republics, the sheer immensity and power of Russia raised the stakes of center-periphery conflict to a qualitatively new level: without Russia, there could be no Soviet Union. That dissolution of the Soviet empire was not a direct goal of the Declaration is irrelevant; the assertion of self-determination by the USSR's linchpin republic was an unprecedented challenge to central Soviet authority. Second, the Declaration (in conjunction with Yel'tsin's speaking tours) helped to encourage similar processes in the autonomous republics within the Russian Federation itself. Third, the Russian Declaration directly involved the leaders of these autonomous republics in the drafting process. Thus, regional elites were offered a "dry run" prior to devising their own decla-

23"Dear comrade deputies! The Secretariat considers it necessary to give several pieces of information for the knowledge of the People's Deputies. To address the ongoing second session of the Supreme Soviet of the TASSR, a great deal of correspondence, telegrams, appeals, statements, and resolutions are arriving. In 15 hours today 685 such documents have been registered, in that number 328 telems, 136 letters, 207 appeals and statements those, 612 were said to be about the question of sovereignty; 50 percent were said to be from Tatariya while the rest came from throughout the Soviet Union (see F.Kh. Mukhametshin, in Stenograficheskiy otchot, Zasedaniye tret'ye, Vtoraya sessiya Verkhovnogo Soveta TASSR, August 28, 1990 [morning session], p. 291). 
rations, during which exercise they acquired a particular vocabulary, style, and set of perceptions with which they returned to their own republics. As a result, the Russian Congress began the process of "sovereignization" in earnest, with unfavorable portents for the process of "federalization" soon to follow.

The Declaration's preamble and fifteen articles outlined its framers' perceptions of sovereignty as historically based in a multiethnic people (Arts. 1 and 3), as a natural and necessary condition for modern statehood (Art. 2), and as the bulwark for various rights and freedoms (Art. 4). In fact, as a correspondent for Pravda wrote at the time, "during the debate it became clear that many of them had different understandings of the very word 'sovereignty'" (see Daniels, 1993, p. 375). Yel'tsin defined sovereignty "from the ground up," by which he literally meant a pyramid flow of authority from the smallest villages to the Supreme Soviet (Lapidus and Walker, 1995, p. 82). Other deputies could be more radical, equating sovereignty with independence and secession. Still others fought over interpretations that were as focused on autonomy from institutions (the USSR, the Party) as on autonomy to action (cultural development, budget formation). A conservative commentator from the Urals colorfully complained: "So, they talk about economic sovereignty, financial, legislative, political, national, regional, religious, and so on. Even about sovereignty of the person. Thereby from this idea they form an image of some fabled many-headed monster, of which the deprivation of one or several heads does not affect its functional characteristics" (Katayev, 1992, p. 40). ${ }^{24}$ There were few areas of genuine agreement, and that perfectly suited the atmosphere of the Congress: "Because sovereignty was an acceptable, longsanctioned word, yet one whose meaning was not agreed, a dialogue could be maintained, despite deep disagreements, and resolutions could be adopted that allowed for different interpretations.... But clarification was not really in anyone's interest. It would have opened the lid to a Pandora's Box of problems, whereas ambiguity allowed agreement to be reached on paper" (McAuley, 1997, pp. 32, 33).

As with any document that unilaterally challenges existing authority, the RSFSR Declaration was of minor legal-constitutional significance (as opposed to its enormous political significance) within the pre-existing Soviet system. Although a crucial precedent was established in leaving existing borders untouched, rights of separate citizenship (Arts. 8, 10,11) exclusive ownership and authority over all "natural riches" (Art. 5, §3), and the primacy of RSFSR law over Union law (Art. 5, \$2) were also asserted. ${ }^{25}$ No legal basis was given for any of these assertions because none could be given: explicit alongside the fiat of these rights was the abrogation of any

${ }^{24}$ Katayev was the head of the Urals higher school of the MVD and dotsent, candidate of law. His complaint continues, hinting at the sort of difficulties such a view of sovereignty created for future approaches to federalism: "An approach of this kind is a failure in theory as it is in practice. Thanks to it the illusion is created that an isolated solution to questions of sovereignty is possible-acquisition of it by parts." existing Soviet law that contradicted them. ${ }^{26}$ The only legal principles that this newly proclaimed "rule-of-law state" (Art. 13) could claim were ephemeral "universally recognized principles of international law" (Art. 14).

Only one of these international principles was specifically expressed, but one that made up for any lack of legal strength by providing a farreaching political resonance that was prone to manipulation: Article 4 announced the inalienable right of every people to self-determination. In this nominally federal state, physically divided according to ethnic groups, the most recent (1989) census indicated that "every people" potentially included over sixty nationalities! Article 7 provided the mechanism for the ultimate exercise of such a right by claiming a right to secession, while Article 9, accepted only after heated debate, affirmed "the need for a substantial broadening" of the existing rights of autonomous republics and other subjects of the Federation. At the time, the increasingly pitched battles for supremacy between Russian and Union authorities (personified in Yel' tsin and Gorbachev), the struggle for control over resources and industry and a Congress dominated by a large ethnic Russian majority left most delegates blind to the precedent they were establishing. As Mary McAuley chronicles, most delegates were left convinced that "the idea of Russia itself breaking up was simply too far-fetched" (McAuley, 1997, p. 34).

With only a few exceptions, there is a remarkable similarity in the final documents advanced by the different autonomous republics, though attempts to explain this fact must rely largely on circumstantial evidence. The similar backgrounds of the drafters and their common reference to an ever-increasing number of preceding declarations are two strong factors. ${ }^{27}$

${ }^{25}$ Extreme caution regarding the redrawing of existing borders was one of the few examples of wisdom and foresight exhibited by political elites in the development of the new Russian federalism. See, for example, Zakon RF "Ob ustanovlenii perekhodnogo perioda po gosudarstvenno-territorial'nomu razgranicheniyu v Rossiyskoy Federatsii," July 3,1992 in Vedomosti $S^{\prime \prime}$ yezda narodnykh deputatov RF $i$ Verkhovnogo Soveta RF, 1992, item 1868, pp. 2397-2398. ${ }^{26}$ The RSFSR Supreme Soviet quickly passed numerous laws and resolutions to strengthen the Declaration's assertions within a new Russian legal framework. On August 9, the resolution "On the defense of the economic basis of sovereignty of the RSFSR" asserted control over the sale of everything from gold to grain (Doronchenkov, 1991, pp. 456-457). An even more exacting law, defining and asserting control over Russia's "natural riches," was signed in late October No mention was made of the rights of ownership accorded sub-union-level territoies (Zakon "Ob obespechil ekonomicheskoy Osnovy suver " the Declaration, on the supremacy of law, was also further developed in late October with the law "On the functioning of acts of organs of the USSR on the territory of the RSFSR" (Adrov and Shakhray, 1991, pp. 16-17).

${ }^{27}$ In explanatory notes to published draft declarations, the RSFSR Declaration and Ukrainian Declaration are cited most often as a point of reference. In Bashkortostan, the RSFSR Ukrainian, and Tatar declarations were all textual influences, while Samigullin emphasizes the "ideological stamp on the head" of drafters subjected to efforts to create "a new Soviet people" as another factor. Interestingly, Samigullin strongly emphasized the influence of the
U.S. Declaration of Independence on the members of the Bashkir drafting committee, though even the closest reading of the final draft offers no textual similarities (Samigullin, 1997). 
While declarations varied in length from six articles (Tatarstan) to eighteen (Adygeya and Marii El), most contained a core of virtually identically phrased articles outlining change in status (from autonomous republic to union republic), the supremacy of republican law, citizenship and its attendant political rights, and republican possession of most everything of value on the republic's territory. Comparing the declarations of many republics, even the order of these claims is often the same.

The declarations themselves, as well as analytical works published subsequently by many of the men and women involved in the Parade of Sovereignties, all point to similar stimuli. According to a monograph coauthored by the current president of Kalmykiya, the legal basis for declaring the sovereignty of his republic was found in the April 10,1990 USSR law "On the fundamentals of economic relations of the USSR, union, and autonomous republics," the April 26 law "On the delimitation of powers...," Art. 9 of the RSFSR Declaration, and speeches by Yel'tsin in the RSFSR Congress of People's Deputies. ${ }^{28}$ Thus, the autonomous republics "had the legislative basis, the moral and legal support of the first Congress of People's Deputies of the RSFSR" (Ilyumzhinov and Maksimov, 1997, pp. 152-155). Boris Zheleznyov, a key drafter of the Tatar declaration, asserted that it was not difficult to see how the RSFSR Declaration and its accompanying debates naturally led to other declarations of self-determination: "The ultimate aim, which the Supreme Soviet of the Republic of Tatarstan pursued, passing the Declaration, was the reorganization of Tatarstan into a sovereign republic - a subject of the USSR as the highest form of soviet federation" Zheleznyov noted the contradiction ("juridical nonsense") caused by the April 26 USSR law in that sovereign republics (former ASSRs with declarations of sovereignty) could find themselves simultaneously subjects of the RSFSR and the USSR (Zheleznyov and Likhachev, 1996, pp. $7,10-11$ ). Irek Muksinov, a member of the USSR Committee of Constitutional Supervision and an active member of the Bashkir Constitutional Commission, identified three linked stimuli for the Parade of Sovereignties in general: (1) new conditions created by glasnost' and democratization freed republican leaders to react directly against the false autonomy proclaimed in Soviet law; (2) union republic declarations, especially that of the RSFSR; and (3) the USSR legislation of 1990-1991, which raised autonomous republics to a higher status (in Ayupov, et al., 1997, pp. 11-12).

Most republics tried to skirt the difficult issue of who exactly possessed the right to self-determination, which all republics employed as a primary justification for sovereignty. Many were reluctant to press an exclusively national basis for the claim, since in less than a third of the republics did

${ }^{28}$ The law "On the delimitation of powers between the USSR and subjects of the Federation" made sweeping grants of principle on the foundations of the Union, declared a basic under exclusive and concurrent jurisdictions. It also granted the right to conclude bilatic treaties, which was an important precedent. See Vedomosti SND SSSR (1990, no. 19, item 329); or English translation in Butler (1991, pp. 45-49). the titular nationality compose a majority of the population; in no republic did the titular nationality account for more than three-quarters of the population, and in half of the republics ethnic Russians accounted for 50 percent or more of the population (Shaw, 1993, p. 532). ${ }^{29}$ In Sakha, for example, Supreme Soviet Chairman Nikolayev's drafting commission specifically ignored efforts by one popular Sakha movement ("Sakha omuk") to link the territory of the republic with the territory of traditional settlements of native peoples (Mironov, 1996, p. 58). Still, many republics made special references in the preamble or first few articles to the special position of the titular ethnic group, their particular inalienable rights singled out above the rights of all other groups. Preambles universally vaunted the "historic responsibility" of republics for their multinational populations, begging the question of exactly whose right to self-determination was being exercised. Most declarations then went on to demand respect and protection for the language and cultures of its titular groups, the more daring declarations also stating a right to protect its ethnic diaspora wherever it was located. Most also sought to appease their Russian populations, too, preserving Russian as an equally protected official language and citing equal protection for political and human rights regardless of nationality. Tatarstan's final draft reflected the national tensions republican leaders cultivated in its preparation: tacked onto the assertion of the inalienable right of ethnic Tatars to self-determination is a feeble inclusion of all other peoples, who, if one were to judge strictly from the awkward phrasing, were also entitled to share in this inalienable right of the Tatar nation. Other ambiguous constructions were hardly accidental, but a clever exercise in political manipulation. Having interviewed several of the key figures involved in its drafting, Valeriy Tishkov reaches a similar conclusion: Shaymiyev and company "were well aware of these doctrinal inconsistencies and had tried to find a creative approach to the text that would allow them to satisfy all major public forces and at the same time exploit ethnonationalism as the major argument to provide bargaining power with the Center" (Tishkov, 1997, pp. 56-57).

Not all declarations were confrontational. In comparison to the unreservedly independent tones of its counterparts, for example, the Declaration of the North Caucasian republic of Kalmykiya is hesitant, compromising, and in parts almost apologetic. The preamble acknowledges the republic's continued status as a subject of both the RSFSR and the USSR and the importance of pursuing economic and social interests in concert with them. Where other republics declared lofty "responsibilities," Kalmykiya placed its right to "socioeconomic progress" and a "rise in the standard of living" on an equal plane alongside self-determination. Other articles noted the continued applicability of Union laws (e.g., Art. 5). Given

${ }^{29}$ Only in Tyva, North Ossetiya, Kabardino-Balkariya, and Chechen-Ingushetiya did the titular elite compose a majority in 1989; in the latter two cases, this is only because of the existence of two titular ethric groups. 
its status as perhaps the poorest republic in the RSFSR, economics provides at least one explanation for this approach. The counsel for the republic's Permanent Mission in Moscow accentuated Kalmykiya's dependence on federal largesse: characterizing all federal units as either "blood-donors" or "blood-recipients," he unabashedly located Kalmykiya with the latter. In such a position, he said, there was no interest in pursuing an activity that might jeopardize much-needed flows of subsidies. What was wanted, and was the underlying purpose of its declaration, was an increased say in how that aid would be applied as well as greater respect for language and cultural rights (Marat, 1995). That Kalmykiya declared at the end of the Parade of Sovereignties further supports the impression of a republic eager not to miss a window of opportunity, but hesitant to jeopardize relations with the center.

A pattern develops in these documents. Republican elites were strongly affected by Yel'tsin's stimulus to grab what sovereignty they could. The result was like the mirror house in a carnival: the RSFSR declaration could be seen reflected in republican versions, slightly refracted to particular circumstance but seldom to the point of losing the original image. The comparatively richer republics advanced stronger claims to resources while the poorer republics aimed to defend their right to federal largesse; republics that feared an exodus of well-trained Russians emphasized more their respect for multiculturalism than republics less dependent on such populations. But the core demands remained virtually untouched: to replace subordinate positions with a new sovereign status; to declare the supremacy of local laws over federal laws; to guarantee autonomy in economic decision-making and control over resources situated on their territory; to accentuate respect for local languages and customs.

\section{EFFECTS ON FEDERAL DEVELOPMENT}

The Russian Declaration of Sovereignty was a document with the sharpest of political motivations, formed out of general confusion about what repercussions its signature focus - sovereignty - specifically entailed. Manipulation not only was inevitable, it had been intentional. Yel'tsin's contest with Gorbachev required allies and resources, both of which a legally vacuous declaration provided at little immediately perceived cost. Declaring control of resources, territory, and state organs was the best way to acquire more political capital. The articles on supremacy of Russian law over Union law and the right to secession implied a sort of transitional authority. A large Congress implied popular legitimacy. Awkward procedural questions were left to be resolved in the Union Treaty, thus developing a strong bargaining position more than six months before the Novo-Ogaryovo process began. Yel'tsin's junket to the republics that August and exhortations to elites there to take as much sovereignty as they could swallow were also part of the strategy intended to constrain Gorbachev's center. Little concern was given to the possibility that if the center ever shifted from Gorbachev to Yel'tsin, these grand promises would be very difficult to keep. Just as Gorbachev legalized a complicated secession procedure, convinced that a renewed, successful Union would dispel any desire to exercise such a right, so Yel'tsin seemed to believe that a "real" federation would devolve all the sovereignty anyone might want, while Moscow retained its strong leadership.

This was a clever gambit. Even one of the principal drafters of the declaration of sovereignty and new constitution of Tatarstan, a republic with a reputation built on swallowing far more sovereignty than Yel' $t$ sin intended, defended such a strategy in light of the times. Boris Zheleznyov is worth quoting at length:

Yel'tsin in all politics is a pragmatist, and he could not fail to understand that he was going to need the support of the republics. ... Gorbachev also launched an attempt to bring to his side the republics. And in particular, in April 1990 another Union law was passed, according to which republics were declared subjects of the USSR, as if subjects of a second sort, preserving autonomy different than the fifteen union republics.... Of course, this was juridical nonsense because one republic, one state, cannot at the same time be a subject of two federations. But many republics accepted this as fact, and their declarations noted that they considered themselves to be union republics - that is, subjects of the Union - at the same time they remained in the Russian Federation. We have a joke about a sturgeon of the "second freshness" - one of the second freshness, that's not a sturgeon! (Zheleznyov, 1997).

Yel'tsin was not concerned that such activity left the constitutions on each of the USSR's federal sub-levels in confusion regarding the federal hierarchy; he merely sought to secure the short-term allegiance of the republics. It was, according to Zheleznyov, not a mistake but simply "a pragmatic move of politics." The problem was that politics of this sort provided shaky foundations for a renewed Union, let alone a renewed Russian Federation. The declarations of sovereignty established a strong negotiating position for Yel'tsin at Novo-Ogaryovo. It is now an academic question whether the structures that were conceived there would have amounted to a durable confederation had the August putsch not prevented their implementation. But building a federation on the vagaries of the sort of "feel-good" sovereignty Yel'tsin propounded was a much more difficult proposition. " ${ }^{30}$ "Yel'tsin] was encouraging the crowd to take freedom and self-determination and he was much loved for it," explained Venir Samigullin, another drafter of declarations and constitutions from Bashkortostan. "If Gorbachev wanted to reform the USSR so that the Union and Autonomous republics would be equivalent, as Sakharov proposed, than Yel'tsin's attracting them to his side was a mistake. But it was not a mistake in the sense that this move gave Russia maximum strength in its argument for independence and freedom, which in the end is what it received" 
(Samigullin, 1997). His promises to the republics were not a mistake from the point of view of Russian independence. But from the point of view of establishing a solid federal approach to new center-periphery relations, Yel'tsin's gambit did little but foment antagonism toward any central involvement in regional affairs, whether that center wore Soviet stripes or Russian ones. Rather than encourage compromise in the renegotiation of autonomy, Yel'tsin incited an all-or-nothing mindset that for the time strengthened him against Union authorities but left him vulnerable to his own promises when he became the embodiment of a new center.

The autonomous republics followed the lead of union republics in declaring sovereignty, but with very different motivations. The most striking of these is the final result that the different types of republics hoped to achieve. In the end, buttressed by declarations of independence in some cases, referendums on independence in most cases and increasing international support, union republics attained the status of sovereign, independent nation-states, distinct entities whose relations with Russia were international in character. This was a goal from the very early stages of their declarations and one with (in most cases) considerable historical precedent behind it. Autonomous republics, for the most part, sought what their name implied: autonomy. In fact, there was considerable concern amongst ASSR elites that their declarations might be misconstrued. "I suggest," worried one member of the Bashkir Supreme Soviet, "it is necessary to more precisely define in our Bashkir Declaration, in order to remove false interpretations, here comrades continue to say that if you become a sovereign republic, they claim that you automatically leave Russia. We are receiving wider rights, we are becoming a republic of a new type. But for many this is not entirely understood" (Pavlov, Stenograficheskiy otchot Verkhounogo Soveta Bashkir SSR, 1990, p. 158).

From the point of view of constructing a "renewed federation," an ambition most republics at least claimed to share in their declarations, the Parade of Sovereignties posed special difficulties in precisely this regard. While some theoretical and comparative work has been done in political

${ }^{30}$ One of the clearest examples of Yel'tsin's schizophrenic, shifting promises is that offered to varying audiences during his 22-day trip through the republics. In Tatarstan, leaving aside his famous remark at the University, his speeches to crowds seemed unambiguous. A future editor of one of the (relatively) more independent newspapers described the effect of the visit: "Naturally, they asked Boris Nikolayevich a newspapers described the effect of the visit: Naturally, the asked Boris Nikolayevich a great many questions about the status of Tatarstan...: will Tatarstan be a union republic, will it leave Russia, what portion of power can it delegate the RSFSR, and who in the event of a declaration of sovereignty will be in charge of the oil? ... And so forth and so forth. It seems, Yel'tsin even grew tired of repeating one and the same thing: These are your questions, these you yourselves should decide, your Supreme Soviet, why do you again want that there should be some kind of instruction from above..." (Yelena Chernobrovkina, "Reshat' vam samim," Vechemyaya Kazan'. August 10, 1990 , p. 1). But asked back in Moscow after his sojoum how he viewed Tan. August 10, Yel'tsin answered: "It remains part of Russia, delegating certain functions to it, and througly, participating in the solution of all-Union questions" [italics added] ("Nuzhny prakticheskiye shagi," Sovetskaya Rossiya, September 2, 1990, p. 2). science about the "sequencing of elections" in transitions from authoritarian rule, little has been said about the sequencing of federal construction in some of those transitions (Linz and Stepan, 1992, pp. 123-139). The theory of electoral sequencing suggests that in democratic transitions it is preferable to engage in all-Union elections prior to regional elections in order to foster unifying agendas and constituencies, the better to construct or reconstruct all-Union institutions conducive to democratic consolidation. Applying the same logic, declarations of sovereignty by definition focused attention on republican interests over those of the center. This was a fact that slowly dawned on Yel'tsin and his advisors as they found themselves the inhabitants of the new center. As Andranik Migranyan complained:

Nowhere in the world have states ever been built on the "from the bottom up" principle, and nowhere has it been said that local government bodies may take as much power for themselves as they want and give the upper levels as much as they deem necessary. Throughout the world, democratic political systems have been formed on the principle of a long and agonizing redistribution of authority and powers from the top down, never the other way around.... Our attempts to create all state institutions from scratch on a contractual basis are attempts to put into effect yet another grandiose utopia.... The bomb planted under the USSR by the declaration of Russian sovereignty is, it seems to me, facilitating not only the destruction of the USSR but also-to an even greater extent-the destruction of Russia itself.... Where are the geographical boundaries of the republic that is supposed to represent ethnic Russians? (Izvestiya, September 20, 1990, p. 3).

Ramazan Abdulatipov, then chairman of the RSFSR Supreme Soviet's Council of Nationalities, echoed this concern, stating that the ASSRs did not realize the full meaning of their actions (Sheehy, 1990, p. 25). In fact, regional leaders seem to have understood all too well. The Parade of Sovereignties offered a special window of opportunity to construct new bases of support as the old foundations on which the nomenklatura had relied were slowly weakening. Regional leaders would have been foolish to ignore such a sweeping chance to unilaterally re-state their relationship with the center. As one regional analyst summarized the result:

On this track, overcoming the stereotypes of a unitary conception of the federal construction of the state was essential. The declaration of state sovereignty of the Russian Federation gave this process a general background and stimulus. By its own political content it was directed to the affirmation of the independence of Russia in the composition of the USSR. But objectively, the declaration pushed the republics, krais, oblasts, and national okrugs 
toward the search for variants of their own independence in the composition of the Russian Federation (Sukharyev, 1993, p. 4). ${ }^{31}$

These variants, however, were formed with a provocative vocabulary not conducive to the compromise and blending of sovereignty and rights that is the basis for a stable federation. Sovereignty, autonomy, self-determination: these were terms that emphasized separateness, individuality, freedom from some indeterminate suppresser of vague inalienable rights. The choice of terms served to direct the course of the debate, establishing the "rules of the game" almost before the players themselves could realize the implications of their actions. Virtually every declaration contained a clause stipulating the document itself, though patently alegal (if not illegal) in the current institutional setting, as the basis for all future participation in negotiations of federal treaties and constitutions. The Russian Declaration of Sovereignty (as part of Yel'tsin's tactical maneuvers against Gorbachev) served to shift the focus of federal debate from the center to the regions. It also encumbered debate about the fate of the Union with local grievances, which, if their appearance was inevitable, at least could have been delayed by an approach that emphasized the search for commonalties in restructuring the federation rather than distinctions and exceptions to it. Before the Parade of Sovereignties, the central issue was simply the loosening of Soviet centralized power; Yel'tsin's gambit led regional elites to question the role of any center, Soviet or Russian. The result was to stimulate the creation of regional agendas, if not before then concurrently with the construction of a general agenda for a renewed federation.

\section{RUSSIAN CONCEPTIONS OF ASYMMETRICAL FEDERALISM}

There are almost as many definitions and theories of federalism as there are theorists to theorize about them, but there appears to be agreement on at least one basic idea: in a would-be federal state, a consensus on the inherent value and basis for forming a federation is critical for success. Ivo Duchacek calls this a "federal political culture"; Arend Lijphart emphasizes "overarching loyalties"; Juan Linz and Alfred Stepan employ a broader concept of the "state-nation" (Duchacek in Elazar, 1991, p. 27; Linz and Stepan, 1996, p. 34). Linz also emphasizes the important, though difficult to quantify, feeling of federal allegiance:

Only complementary principles like that of solidarity, Ausgleich, Angemessenheit, Bundestreue compensate for that fundamental differentiation with the same demos. Those principles are generally vaguely defined, difficult to operationalize, subject to consid-

${ }^{31}$ Sukharyev is director of the scientific research institute of regional studies at Mordova State University in Saransk. erable negotiation between the center and the periphery, and often left to the interpretation of constitutional courts. They are principles that escape largely the decision-making of the electorate of the demos of the state and sometimes of the demoi of the sub-units and only complement the basic principles of federalism, although they are in a sense the soul of a working federalism (Linz, 1997).

A consensus on the inherent value of the federal project is critical for success. For Russia's regional and federal elites before, during, and now reaching the end of first attempts at institutional engineering, such a consensus has been crucially lacking. Disagreement over the "soul of a working federalism" is a fundamental problem facing the Russian Federation and a direct descendant of earlier debates over sovereignty.

Republican elites who spearheaded regional campaigns against Yel'tsin's center also held notions of federalism strongly influenced by Soviet experience, but the very opposite of Moscow's centrist conclusions. These preconceptions - following years of subordination in ASSRs - were encouraged by Yel'tsin's dissembling demands against Gorbachev for the loosest of confederal relations.

A pervasive belief among republican elites was that lasting federal solutions could only be constructed snizu vverkh, "from the bottom up," with regional powers unabridged and superior to those of the federal government. Yel'tsin's summer 1990 advice to elites to take all the sovereignty they could swallow planted the seeds for this thinking. In Bashkortostan, the Chairman of the Supreme Soviet parroted Yel'tsin as he and his fellow deputies shrugged off the guiding hand of federal authorities: "we appealed to Boris Nikolayevich Yel' tsin during his visit in Bashkiriya: how does he see the future structure in the Soviets on different levels? He answered: 'As the [republican] Supreme Soviet takes a solution, so it will be, because we can't dictate our own conditions of the Center. In the Kuban one [solution] should be, in Bashkiriya-one, in Tatarstan-another. Therefore, please, consider it at your own Supreme Soviet'" (Stenograficheskiy otchot Izdaniye Verkhovnogo Soveta Bashkirskoy ASSR, 1990, p. 15). Rashit Vagizov, Chairman of the Committee on Questions of Legislation, Legality, Law and Order, and Deputies' Ethics in the Tatarstan Parliament, insists that the voluntary delegation of power "from the bottom up" is a core principle of federalism (Vagizov, 1997).

How this principle should translate into action has been articulated in a variety of ways, but Tatarstan's leaders produced the dominant lexicon for future federal debates in Russia. Its most eloquent proponent is Raphael Khakimov, a personal advisor to the Tatar President: "There are two basic approaches to the federalization of Russia: one is constitutional-treaty, the other is treaty-constitutional" (Khakimov, 1996a, p. 70; Khakimov in Iskhakov, 1994, pp. 58-65). The constitutional-treaty approach was the straw man, "traditional of the official structures of Russia" (a euphemism for Russian authoritarianism), which Khakimov promised would lead to a dominant center and ever-weaker republics. In contrast, the treaty-consti- 
tutional approach demanded "establishing relations with the central government 'from below upwards,' i.e., through the voluntary transfer of their authority by means of bilateral treaties. In this case, sovereignty becomes a necessary legal basis for the self-determination of the subjects of the Federation." Khakimov calls this sort of government "concordant federation" (Khakimov, 1996a, p. 70). The phrase "treaty-constitutional" quickly proliferated in official documents, a sign that this had become more than an academic catchphrase (Khakimov, 1996b, pp. 23-24; Shaymiyev in Valeyeva, 1993, p. 7)..$^{32}$

Whether articulated as principle ("from the bottom up") or system ("treaty-constitutional relations"), republican elites signaled their rejection of the more accepted federal principle that federation entails a pooling and reduction of the individual sovereignties of constituent units into a new, fully sovereign entity. In the eyes of republican leaders, their newly declared sovereignty was neither divisible nor diminishable by a new Russian Federation. While economic and security considerations (at the very least) made secession a moot point for all but Chechnya, republican elites were reluctant to part with a right to secede in principle (Samigullin, 1993 , p. 17) ${ }^{33}$ Declarations of sovereignty and republican constitutions drew from these principles the view that republican laws (by virtue of state sovereignty) retained supremacy over federal legislation. A hierarchy implicit in the treaty-constitutional approach raised republics above the federal government in all matters save those explicitly transferred by the republics, which reserved the right to redeem such powers. From the point of view of the republics, in contrast to accepted federal theory, the Russian Federation was not greater than the sum of its parts.

A "treaty-constitutional" approach meant not federation but a loose confederation of sovereign states. Regional elites point to Article 11, $\$ 3$ of the federal constitution, which establishes that the division of powers is determined "by the present constitution and the Federation Treaty and other treaties." Federal elites hold the reverse view: the Federation is a freestanding sovereign entity that neither required nor sought nor took its justification from its member units (e.g., Sergey Shakhray; see Guboglo and Arinin, 1997, p. 153). ${ }^{34}$ They point to Article 15, $\$ 1$ of the federal constitu-

${ }^{32}$ The law "On the order introducing into action the Constitution of the Republic of Tatarstan," passed approximately three weeks after acceptance of that constitution, appeals to the Russian Federal Supreme Soviet to construct "treaty-constitutional relations" between the republic and the Federation. An official letter to Yel'tsin sent roughly five months later by Shaymiyev and the Chairman of the Supreme Soviet of Tatarstan, Farid Mukhametshin, restates this special relationship. President Shaymiyev himself has used both the phrase snizu voerkh and dogovorno-konstitutsionnyy to describe what "international experience" shows is the best guarantee of federal stability.

${ }^{33} \mathrm{~A}$ leading member of the Bashkir Constitutional Commission, V.K. Samigullin, argued that as Bashkortostan had voluntarily entered into the composition of Russia (in 1557) and then into the RSFSR (in 1919), in the new Bashkir Constitution "... it would be expedient to provide
in for a right of the Bashkir nation to separation, to exit from the composition of the Russian Federation." tion, which establishes the "supreme legal force and direct effect" of the constitution above any other law or legal act. In an interview with Rossiyskiye vesti in 1994, Yel'tsin's then-chief-of-staff Sergey Filatov summarized aspects of this orientation in both regional and federal elites: "The most general trends are the aspiration of the republic elites to represent the powers of the Russian Federation as the sum of powers delegated by the components (this is, notably, characteristic of the constitutions of Bashkortostan, Buryatiya, Sakha, Tatarstan, and Tuva). However, the powers of the Russian Federation ensue from its own sovereignty as a single, integral federative state, and they do not depend on the components" (FBIS Daily Report: Central Eurasia, September 2, 1994, p. 18).

The Parade of Sovereignties was precursor to a "Parade of Bilateral Treaties," and this has been the second serious effect on the conceptual development of Russian federalism. Forty-six of the eighty-nine units of the Federation have bilateral treaties with the federal government, starting with Tatarstan on February 14, 1994 and including, most recently, the City of Moscow on June 16, 1998. By the end of 1998, eleven republics (52 percent) had successfully negotiated bilateral treaties. ${ }^{35}$ These treaties are highly political arrangements, entering into force exclusively on the authority of the executive branch of the respective federal and regional governments. Until recently, treaties have entered into force without the requirement of ratification by either the federal or regional legislatures; thus, it is very difficult to place them in the hierarchy of existing constitutional laws and norms. ${ }^{36}$ Treaties have been under the exclusive control of the federal executive (Yel'tsin) and the executive branches of republics and other regions. Thus, the political bargaining about the very core principles of Russian federalism that began with declarations of sovereignty continued with the negotiation of treaties and agreements, frequently by the very same political actors still in office. At the end of May 1994 Yel'tsin declared: "I have not renounced my formula: 'Take as much sovereignty as you can swallow'" (Tregubova, in Segodnya, May 31, 1994, p. 1).

Federal and republican elites are divided as to whether the Russian Federation is a "constitutional-treaty" or a "treaty-constitutional" entity. The multiplicity of treaties and agreements has done little to clarify issues

${ }^{34}$ Sergey Shakhray notes, "One thing may be firmly stated-the contemporary practice of concluding treaties does not mean a transformation of our federation from a constitutional to a constitutional-treaty or to a treaty [based federation]. The federal constitution is the legal basis of our federative state and its effective functioning."

${ }^{35}$ The treaty signed with Chechnya in May 1997, essentially an armistice agreement, bore little resemblance to any other bilateral treaty (see Otto Latsis, Izvestiya, May 14, 1997, p. 1). The total number of treaties as of June 16, 1998 was as follows.

Federation subject Total number of units Number with treaties Percent

Republics

Oblasts

Krays and AOs

Federal cities

$\begin{array}{rr}21 & 111 \\ 49 & 26 \\ 17 & 8 \\ 2 & 2\end{array}$


of immediate jurisdiction or to establish principles for the resolution of future center-periphery conflicts. Despite the proliferation of treaties, the RF Ministry of Justice announced in late 1996 that 19 of 21 republican constitutions - virtually all of which refer for justification to their declared sovereign rights - violated the federal constitution (Nagornykh, in Segodnya, November 22, 1996, p. 2). The so-called "War of Laws," coincident with the Parade of Treaties, has produced thousands of republican laws that contradict the federal constitution, federal law, and sometimes even the very treaties that have been negotiated (Dokuchayev, in Izvestiya, November 4,1997, p. 1).37

In the Russian lexicon, this is a problem of the "supremacy of laws." Virtually all republics declare the supremacy of republican law to some degree. Most republics utilize the language of snizu vverkh or "treatyconstitutional relations," noting that federal authority extends only so far as those powers delegated to the federation. Some statements are starkly unilateral, such as Ingushetiya's declaration (in Article 7) that federal legislation is "lawful" only insofar as it does not impinge the "sovereign rights" of the republic (Konstitutsii Respublik v sostave Rossiyskoy Federatsii, 1995 , pp. 65-81). The Republic of Sakha is another example, requiring federal legislation to pass a vote in the lower chamber of its parliament before accepting its jurisdiction (Konstitutsiya (Osnovnoy zakon) Respubliki Sakha (Yakutiya), 1995, Article 41). Several republics, such as Adygeya (Art. 56) and Dagestan (Arts. 1 and 65), reserve the right to suspend federal legislation, either pending appeal to an agreed body of arbitration or simply upon the decision of the republican authorities (Konstitutsii Respublik..., 1995).

These are extraordinary claims with serious implications for a federation. These republics do not recognize a unified legal space for the federation, which is beyond appeal to their sovereign idiosyncrasies. According to Yel'tsin's advisor on legal questions, Mikhail Krasnov, Tatarstan and Bashkortostan simply "do not take in Russia's judicial system" (Katanyan,

${ }^{36}$ On July 30, 1999 a new federal law entered into force, "On the principles and manner of demarcation of subjects of jurisdiction and authority between organs of state power of the Russian Federation and organs of state power of subjects of the Russian Federation" (Sobraniye, 1999, item 3176, pp. 5685-5692; Sadchikov, Izvestiya, 30 July 1996, p. 2; Golovanov, 1999). This law seeks to formalize the process of treaty-making. It emphasizes the supremacy of the RF Constitution and federal law over treaties and agreements (Art. 4) and the principles of constitutionality and glasnost' in concluding these instruments (Arts. 3 \& 10). However, should be noted that the law envisions examination (rassmotreniya) NOT ratification fede be noted that the law envisions examination (rassmotreniya), NOT ratification b) the pross seems likely to branches prior to the adoption of new treaties (Art. 23). Thus periocen period during which existing treaties and agreements are to be brought into conformity with federal law (Art. 32). Whether this law will succeed in the restructuring of the bilateral treaty process it proposes (where numerous predecessors have failed), or falls prey to the pitfalls of malfeasance and non-enforcement that have afflicted judicial, ministerial and procuracy activity is still very much an open question.

${ }^{37}$ According to one report, approximately 22,000 regional laws and executive orders contradict the federal constitution. in Nezavisimaya gazeta, February 12, 1998, p. 3). This view undergirds statements such as those of Aleksandr Kim, the president of the Sakha Republic's Association of Banks:

As you know, in Russia shortly will be accepted new laws on banking activity, which materially strengthen and widen the rights and resources of banks. The board of directors is now conducting work on the parallel preparation of new laws of the Republic of Sakha on banking activity, insofar as acceptance of new Russian [federal] laws still does not mean that they will work on the territory of the republic if they will not be in conformity with our new laws (Kim, 1996, p. 3).

This conception demands that federal laws be locally approved prior to implementation, or in some way correspond to the varying levels of authority republics are willing to offer for federal jurisdiction, as through the use of bilateral treaties. Laws that fail this test may be suspended or simply "lose force" on their territories. This is a doctrine of nullification (popular in America's antebellum South, where its leading exponent was John C. Calhoun), which asserts that the federal government's proper role is as an agent of the component states. Thus, states are within their rights to selectively reject federal laws (or their agency) when they conflict with state interests. Nullification alters federal presumptions to strongly confederal ones. It interprets a constitution to be not a foundational document against which disputes should be judged by a court, but as a political compact that individual states, as signatories, have the right to interpret and renegotiate against their own interests. As Keith Whittington observed of the debate in the United States in the 1830s: "For the nullifiers, federalstate relations required political, not legal, settlements. The judiciary has no distinctive claim in an intrinsically political dispute. Consequently, inviting judicial intervention would be tantamount to inviting any other form of federal political control over the states. Moreover, as a political conflict, the successful resolution of federal-state disputes necessitated, from the states' perspective, that the states have effective political influence" (Whittington, 1996, p. 9).

An anarchic legal-political environment is a serious problem for any state, especially one in supposed transition to democracy. In a federation, which by definition encourages a certain level of decentralization and protected spheres of autonomy, the problems presented by such a war of laws are much more difficult to resolve. In a multiethnic federation like Russia, struggling under the debilitating legacies inherited from the Soviet past, the transition to a rule-of-law democratic state has been seriously undermined by a more recent conceptual legacy of the Parade of Sovereignties. While few republics intended declarations of sovereignty to be precursors to independence, all republics viewed these documents as reassertions of their long-promised autonomy. Declarations of sovereignty were used as foundations for new republican constitutions and starting 
points for negotiation of the new Russian federalism. The extreme conception of republican rights that they introduced in a Parade of Sovereignties has returned to the fore of federal debates in a Parade of Treaties, with serious portents for the future of Russia's experiment with federalism and presumed transition to democracy.

\section{REFERENCES}

Adrov, A. N. and S. M. Shakhray, eds., Sbornik zakonodatel'nykh aktov RSFSR o gosudarstvennom suverenitete, soyuznom dogovore $i$ referendume. (Collection of legislative acts of the RSFSR on state sovereignty, the union treaty, and referendum). Moskva: Sovetskaya Rossiya izdatel'stvo, 1991.

Ayupov, M. A., I. A. Adigamov, I. Sh. Muksinov, F. R. Muratshin, V. Ye. Safonov, and I. M. Yulbarisov, eds., Stanovleniye dogovornykh otnosheniy Respubliki Baslikortostan Rossiyskoy Federatsii (1990-1996 g.) (Sbornik dokumentov) (The establishment of treaty relations between the Republic of Bashkortostan and the Russian Federation [19001996] [Collection of documents]). Ufa, 1997.

Belyayev, Vladimir (Chief of the Department of Sociology and Political Science at Kazan' State Technical University and leader of the political group "Social Democratic Union"), Kazan', June 2, 1997.

Brady, Henry E. and Cynthia S. Kaplan, "Eastern Europe and the Former Soviet Union," in David Butler and Austin Ranney, eds., Referendums Around the World: The Growing Use of Direct Democracy. Washington, DC: American Enterprise Institute, 1994.

Brown, Archie, "The Russian Crisis: Beginning of the End or End of the Beginning?" Post-Soviet Affairs. 15, 1: 56-73, 1999.

Butler, William E., Basic Documents on the Soviet Legal System. 2nd ed,, London, UK: Oceana, 1991.

Chernobrovkina, Yelena, (Political Editor, Vechernyaya kazan'), interview with David Hoffman, Kazan, Tatarstan, June 2, 1997.

Chervonnaya, S. M. and M. N. Guboglo, eds., Probuzhdeniye finno-ugorskogo severa. Tom 1: Natsional'nyye dvizheniya Marii El (The awakening of the Finno-Ugric north. Volume 1: National movements of Marii El). Moskva: RAN Tsentr po izucheniyu mezhnatsional'nykh otnosheniy, instituta Etnologii i Antropologii, 1996.

Daniels, Robert V., ed., A Documentary History of Communism in Russia: From Lenin to Gorbachev. Hanover, NH: University Press of New England, 1993.

Doronchenkov, A. I., ed., K Soyuzu suverennykh narodov: Sbornik dokumentov KPSS, zakonodatel'nykh actov, deklaratsiy, obrashcheniy i presidentskikh ukazov, posvyashchonnykh probleme natsional'no-gosudarstvennogo suvereniteta (Towards a union of sovereign peoples: Collection of documents of the CPSU, legislative acts, declarations, addresses, and presidential decrees dedicated to the problem of national-state sovereignty). Moskva: Institut teorii i istorii sotsializma TsK KPSS, 1991.

Elazar, Daniel, J., ed., Constitutional Design and Power-Sharing in the Post-Modern Epoch. New York, NY: University Press of America, 1991.

Farukshin, M. Kh., "Politicheskaya elita v Tatarstane: Vyzovy vremeni i trudnosti adaptatsii" (The political elite in Tatarstan: Challenges of the times and difficulties of adaptation). Polis: Politicheskiye issledovaniya 6, 24: 67-79, 1994

"Filatov on Center-Region Constitutional Issues," FBIS Daily Report: Central Eurasia. FBIS-SOV-94-171, September 2, 1994.
Golovanov, Leonid, "Dogovor-ne sgovor" (A treaty is not a deal), Rossiyskaya Federatsiya 15: 21-22, 1999.

Guboglo, M. N. and A. N. Arinin, eds., Federalizm vlasti i vlast' federalizma (The federalism of power and the power of federalism). Moskva: TOO IntelTex, 1997.

Hanson, Philip, Regions, Local Power and Economic Change in Russia. London: Royal Institute of International Affairs, 1994.

Hughes, James, "Regionalism in Russia: The Rise and Fall of Siberian Agreement," Europe-Asia Studies, 46, 7; 1133-1161, 1994.

Ilyumzhinov, K. N. and K. N. Maksimov, Kalmykiya na rubezhe vekov (Kalmykia on the edge of the ages). Moskva: Izdatel'stvo "ZelO," 1997.

Iskhakov, D. M., ed., Sovremennyye natsional'nye protsessy v respublike Tatarstan (Contemporary national processes in the republic of Tatarstan). Kazan': Akademiya nauk Tatarstana, Institut yazyka, literatury, i istorii im. G. Ibralimova, 1994.

Katayev, N. A., "Problemy pravovoy reglamentatsii statusa respublik Rossiyskoi Federatsii (Problems of legal regulation of the status of republics of the Russian Federation)," in N. A. Katayev and V. K. Samigullin, eds., Problemy konstitutsionnogo razvitiya suverennoy respubliki. (Problems of constitutional development of a sovereign republic). Ufa: Izdaniye Verkhovnogo Soveta i Soveta ministrov Respubliki Bashkortostan, 1992.

Khakimov, Raphael S., "Prospects of Federalism in Russia: A View from Tatarstan," Security Dialogue, 27, 1:69-80, 1996a.

Khakimov, R., ed., Belaya kniga Tatarstana: put' $k$ suverenitetu, 1990-1995 (The white book of Tatarstan: Path to sovereignty, 1990-1995). Kazan': Tsentr gumanitarnykh proyektov $\mathrm{i}$ issledovaniy, 1996b.

Kim, A. N., Pravovyye aspekty perekhodnogo perioda v respublike Sakha (Yakutia) (Legal aspects of the transitional period in the republic of Sakha (Yakutiya)). Yakutsk: Sakhapoligrafizdat, 1996.

Konstitutsii Respublik v sostave Rossiyskoy Federatsii. Vypusk 1. Moskva: Izdaniye Gosudarstvennoy Dumy, Izvestiya, 1995.

Konstitutsiya (Osnovnoy zakon) Respubliki Sakha (Yakutiya). Yakutsk: Natsional'naya izdatel'sko-poligraficheskaya kompaniya "Sakapoligrafizdat," 1995.

Lapidus, Gail W. and Edward W. Walker, "Nationalism, Regionalism, and Federalism: Center-Periphery Relations in Post-Communist Russia," in Gail Lapidus, ed., The New Russia: Troubled Transformation. Boulder, CO: Westview Press, 1995.

Lieven, Anatol, Checinya: Tombstone of Russian Power. New Haven: Yale University Press, 1998.

Linz, Juan J., “Democracy, Multinationalism, and Federalism.” Paper presented at the International Political Science Association Meeting in Seoul, Korea, August 1997.

Linz, Juan and Alfred Stepan, "Political Identities and Electoral Sequences: Spain, the Soviet Union, and Yugoslavia," Daedalus. 121, 2:123-139, Spring 1992.

Linz, Juan J. and Alfred Stepan, Problems of Democratic Transition and Consolidation. Baltimore: Johns Hopkins, 1996.

Mann, Dawn, "Leadership of Regional Communist Party Committees and Soviets," Report on the USSR, 2, 51:15-25, 1990 .

Marat, Batyshin, (counsel, Permanent Mission of the Republic of Kalmykiya). Moscow, July 7, 1995.

McAuley, Mary, Russia's Politics of Uncertainty. Cambridge: Cambridge University Press, 1997. 
McFaul, Michael and Nikolay Petrov, eds., Politicheskiy al'manakh Rossii 1997 (Political almanac of Russia, 1997). Moskva: Moskovskiy Tsentr Karnegi, 1998.

Mironov, Dmitriy N., Konstitutsionno-pravovoy status respubliki sakha (Yakutiya) kak $s u b^{\prime \prime}$ yekta Rossiyskoy Federatsii (Constitutional-legal status of the republic of Sakha (Yakutiya) as a subject of the Russian Federation). Novosibirsk: "Nauka" sibirskaya izdatel'skaya firma RAN, 1996.

Samigullin, V.K., Konstitutsiya Respubliki Bashkortostan (voprosy teorii). Ufa: Bashkirskiy Gosudarstvennyy Universitet, 1993.

Samigullin, Venir K., (professor of law, Bashkir State University), Ufa, Bashkortostan, April 28 and 30, 1997.

Shaw, Denis J. B., "Geographic and Historical Observations on the Future of a Federal Russia," Post-Soviet Geography. 34, 8:530-540, 1993.

Shaymiyev, M. S., "Privetstviye prezidenta respubliki Tatarstan M. Shaymiyev," in Zilya R. Valeyeva, ed., Mezhdunarodnaya nauchno-prakticheskaya konferentsiya "Federalizm - global'nyye i rossiyskiye izmereniya." Kazan': Tipografiya Tatarskogo gazetnozhurnal'nogo izdatel'stva, 1993.

Sheehy, Ann, "Fact Sheet on Declarations of Sovereignty," Report on the USSR, 2, 45:23$25,1990$.

Sobraniye zakonodatel'stoa Rossiyskoy Federatsii (Compendium of legislation of the Russian Federation). Moscow, June 28, 1999.

Stenograficheskiy otchot, Tret'ya sessiya Verkhovnogo Soveta Bashkirskoy SSR (dvenadtsatyy sozyv), 10-13 oktyabrya 1990 g., 23-24 octyabrya $1990 \mathrm{~g}$. (Stenographic record, Third session of the Supreme Soviet of the Bashkir SSR, twelfth convocation). Ufa: Izdaniye Verkhovnogo Soveta Bashkirskoy SSR, 1991.

Stenograficheskiy otchot, Zasedaniye pervoye, Vtoraya sessiya Verkhovnogo Soveta TASSR (Stenographic record, First meeting, Second session, Supreme Soviet of the Tatar ASSR). August 27, 1990 (morning session).

Stenograficheskiy otchot, Zasedaniye tret'ye, Vtoraya sessiya Verkhovnogo Soveta TASSR. August 28, 1990 (morning session).

Solnick, Steven L., Stealing the State: Control and Collapse in Soviet Institutions. Cambridge, MA: Harvard University Press, 1998.

Sukharyev, A. I., ed., Regional'naya politika Rossiyskoy Federatsii (Regional policy of the Russian Federation). Saransk: NII regionologii, 1993.

Sultanov, Ildus (Chairman of the executive committee of the "Equality and Law" electoral bloc), Kazan', June 1, 1997.

Tishkov, Valery, Ethnicity, Nationalism and Conflict In and After the Soviet Union: The Mind Aflame. London: Sage, 1997.

Toropov, Dmitriy, Spravochnik novykh partiy i obshchestvennykh organizatsiy Tatarstana (Handbook of new parties and public organizations of Tatarstan). Moskva: Informatsionno-ekspertnaya gruppa "Panorama," 1992.

Urazayev, Farit (member, Tatar Public Center), Kazan', June 2, 1997.

Vagizov, Rashit G., Kazan', June 10, 1997.

Vedomosti S"yezda narodnykh deputatov RF $i$ Verkhovnogo Soveta RF, No. 32, August 13, 1992.

Vedomosti S"yezda narodnykh deputatov RSFSR v Verkhovnogo Soveta RSFSR, No. 22, November 1, 1990.

Vneocherednyaya Vtoraya Sessiya Verkhovnogo Soveta Bashkirskoy ASSR Dvenadtsatogo Sozyva Zasedaniye Pervoye, Stenograficheskiy otchot Izdaniye Verkhovnogo Soveta Bashkirskoy ASSR. Ufa, September 3, 1990.
Whittington, Keith E., "The Political Constitution of Federalism in Antebellum America: The Nullification Debate as an Illustration of Informal Mechanisms of Constitutional Change," Publius, 26, 2: 1-24, 1996.

Yavlinsky, Grigory, "An Uncertain Prognosis," Journal of Democracy, 8, 1:3-11, 1997. Zaymullin, Zaaki (member, Tatar Public Center), Kazan', June 2, 1997.

Zheleznyov, Boris L. (professor of law, Kazan' State University), Kazan', June 6, 1997.

Zheleznyov, Boris and Vasiliy Likhachev, Pravovoy status respubliki Tatarstan (Legal status of the republic of Tatarstan). Kazan': Tatarskoye knizhnoye izdatel'stvo, 1996. 